\title{
Öğretmenlerin Karşılaştıkları Ekonomik Sorunlar ve Maaş Artışı Talepleriyle İlgili Görüşleri: Twitter Analizi
}

\section{Economic Problems Faced by Teachers and Their Views on Salary Increase Demands: Twitter Analysis ${ }^{1}$}

\section{Gökhan CANTÜRK ${ }^{1}$}

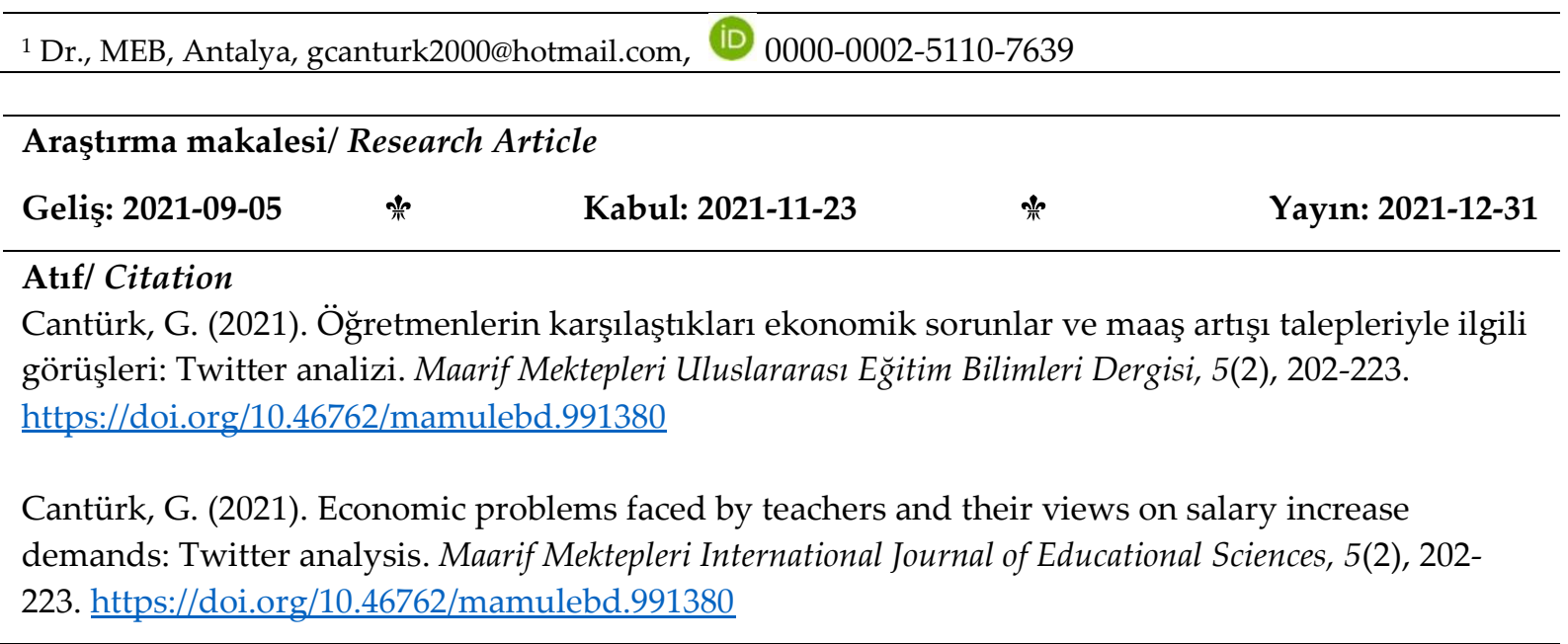

Öz

Eğitimin bir ülkenin gelişmesindeki en önemli araçlarından biri olduğu düşünüldüğünde, öğretmenlerin bu süreçteki en önemli öğelerden biri olduğu söylenebilir. Öğretmenlik mesleği genel kültür, özel alan ve pedagojik formasyon bilgisi gerektiren bir uzmanlık alanıdır. Bir milletin geleceğini hazırlama sorumluluğu taşıyan öğretmenler, genç kuşakların yetiştirilmesinde ve eğitilmesinde önemli bir role sahiptir. $\mathrm{Bu}$ nedenle öğretmenlerin görevlerini en iyi şekilde yapabilmeleri için öncelikle mesleğe başlamadan önce iyi bir süreçten geçmeleri, daha sonra ise mesleklerini icra ederken en iyi verimin alınabilmesi için uygun koşulların sağlanması gerekmektedir. Günümüzde eğitim alanında meydana gelen olaylara tepki aracı olarak sosyal medyanın (twitter, facebook, instagram) kullanımı önemli hale gelmiştir. Dünya'da ve Türkiye'de sosyal medyanın kullanımının artışı göz önünde 
bulundurulduğunda eğitim alanında meydana gelen olaylarla ilgili yansımaların twitter gibi platformlarda gündeme gelmesinin kaçınılmaz olduğu söylenebilir. Bu çalışmanın amacı, öğretmenlerin karşılaştıkları ekonomik sorunlar ve maaş artışı talepleri hakkında görüşlerini belirlemektir. Bu amaç çerçevesinde sosyal medya platformu Twitter'1 kullanarak paylaştıkları 5925 tivit incelenmiştir. Araştırma verileri 23 Haziran 2021-26 Haziran arasında açılan \#öğretmenmaasıyetmiyor etiketi üzerinden Maxqda programı üzerinden elde edilmiştir. Çalışmada nitel araştırma yöntemlerinden doküman incelemesi yapılmış olup elde edilen veriler üzerinden sosyal ağ analizi gerçekleştirilmiştir. Maxqda programina ait görsel seçenekler kullanılarak araştırmaya ait bulgular sunulmuştur. Ayrıca raporlaştırılan kodların ve temaların desteklenmesi için gerçekleştirilen twitter etkinliğinde paylaşılan resimler de kullanılmıştır. Katılımcıların tivitleri incelenip temalaştırıldığında etkinliğe olumlu anlamda destek olduğu görülmektedir. Bu tivitler analiz edildiğinde olumlu mesajların öğretmenler ve diğer meslek gurupları tarafından yazıldığı söylenebilir.

Anahtar Kelimeler: Öğretmen maaşları, ekonomik sorunlar, maaş artışı, twitter analizi

\section{Abstract}

When considered that education is one of the most important tools in the development of a country, it can be said that teachers are one of the most important elements in this process. Teaching profession is an area of specialization that requires knowledge of general culture, special field, and pedagogical formation. Teachers, who are responsible for preparing the future of a nation, have an important role in raising and educating the younger generations. For this reason, for teachers to perform their duties in the best way, they must first go through a good process before starting their profession, and then provide appropriate conditions for the best efficiency while performing their profession. Today, the use of social media (Twitter, Facebook, Instagram) as a means of reaction to events in the field of education has become important. Considering the increase in the use of social media in the world and in Turkey, it can be said that it is inevitable that the reflections about the events taking place in the field of education come to the fore on platforms such as twitter. The purpose of this study is to determine the economic problems faced by teachers and their views on salary increase demands. For this purpose, 5925 tweets shared by teachers using the social media platform Twitter were analyzed. The research data were obtained, via the twitter link of Maxqda program through the hashtag"\#teacher'ssalaryisnotenough" opened between June 23 and June 26-2021. In the study, document analysis which is one of the qualitative research methods, was done and social network analysis was carried out on the data obtained. Findings of the research are presented by using the visual options of the Maxqda program. Moreover, pictures shared in the twitter event held to support the reported codes and themes were used too. When the tweets of the participants are examined and themed, it is seen that they support the event positively. When these tweets are analyzed, it can be said that positive messages were written by teachers and other professional groups.

Keywords: Teachers' salary, economic problems, salary increase, twitter analysis

\section{Giriş}

1739 sayılı Milli Eğitim Temel Kanununa göre "Öğretmenlik, devletin eğitim, öğretim ve bununla ilgili yönetim görevlerini üzerine alan özel bir ihtisas mesleğidir." $\mathrm{Bu}$ tanım çerçevesinde öğretmenliğin uzmanlık gerektiren bir meslek olduğu söylenebilir. İçinde bulunduğumuz dönemde öğretmenlik, eğitim alanı içerisinde sosyal, kültürel, ekonomik, bilimsel ve teknolojik yeterlilik alanlarına sahip olması 
gereken, branşında özel uzmanlık bilgi ve becerisi isteyen, akademik birikim ve öğretmenlik formasyonu gerektiren, uzmanlık statüsünde uğraşı alanı olarak görülmektedir (Hacıoğlu ve Alkan, 1997). Ĕ̆itimcilerin öğretmenlik mesleğini icra ederken, eğitimcilik ve bilgiye erişimde yol göstericilik rolü, model olma rolü, liderlik rolü, değişimci-yenilikçi rolü, rehberlik rolü ve ana baba rolü göstermeleri gerekmektedir (Helvac1, 2007, 293-297).

Öğretmenlik mesleği, öğrenim sürecinde olan kuşağı, milleti, devleti, vatanı, ailesi ve çevresi için her zaman faydalı, geliştirici, milli ve manevi değerlerine bağlı, üreten, iyi bir insan ve iyi bir vatandaş olarak eğitme işidir. Öğgretmenlerin bu şekilde eğittiği nesil, ailesinin ve milletinin gurur kaynağı olur, vatanını bayındır eder, devletini kuvvetlendirir. Bu çerçevede, milletimizin, vatanımızın ve devletimizin istikbali, ülkemizin muasır medeniyet seviyesine ulaşma hedefini gerçekleştirmesi, öncelikle öğretmenlerin eğitim-öğretim sürecinde gösterecekleri başarıya bağlıdır. Gazi Mustafa Kemal Atatürk, Türk milletinin gerçek istiklalini öğretmenlerle birlikte gerçekleştireceğini belirtmiş, İstiklal Savaşı sırasında ve Cumhuriyet kurulduktan sonra, öğretmenler ve öğretmenlik mesleği için: “Milletleri kurtaranlar yalnız ve ancak öğretmenlerdir. Öğretmenden, eğitimden mahrum kalan bir millet henüz millet adını alma istidadını kazanmamıştır. Ona alelade bir kitle denir, millet denmez. Bir kitle millet olabilmek için mutlaka eğitimcilere ve öğretmenlere muhtaçtır." (Türk Devrim Tarihi Enstitüsü, 1961) ifadelerini kullanmıştır.

Öğretmenlik mesleğinin toplumdaki statüsünü tanımlarken bazı ölçütlerden yararlanılabilir. Bu ölçütlere; öğretmenlerin aldıkları ücretlerin diğer meslekler ile karşılaştırılması ve bu gelirlerinin adil olup olmadığı, gençlerin öğretmen olma istekleri, toplumun ve öğrencilerin öğretmenlere gösterdikleri sayg1, öğretmenlerin sosyal statüsü, kamuoyuna göre öğretmenlerin alması gereken maaş, toplumun eğitim sistemine duyduğu güven endeksi, sendikaların öğretmenlerin özlük haklarını iyileştirmede etkinlik başarıları gibi konu başlıkları örnek verilebilir (Varkey GEMS Foundation, 2013). Bu konu başlıklarına ek olarak, öğretmenlerin toplumda gösterdiği kültürel, ekonomik ve sosyal rollerinin iyi tanımlanmasının gerektiği söylenebilir. Bu çerçevede söylenebilecek ilk olgu mesleğin ekonomik yönüdür. Doktorluk, avukatlık ve mühendislik gibi mesleklerin kazançlarıyla, öğretmenlerin aldıkları ücret karşılaştırıldığında, öğretmenlik mesleğinin statüsünün düşük olduğu yorumu yapılabilir (Göker ve Gündüz 2017).

657 sayılı Devlet Memurları Kanunu'na göre öğretmenlerin diğer kamu hizmeti yapan memurlar gibi ekonomik hakları vardır. Öğretmenler, hangi derece-kademede olduklarına bağlı olarak ve diğer özel durumlara göre aylık maaşlarını kazanırlar. Ayrıca, öğretmenler eğitim-öğretim tazminatı, maaşları karşılı̆̆ı okutmak zorunda oldukları haftalık ders saatinden fazla okuttukları dersler için ek ders ücreti, uzman öğretmenlik, çocuk yardımı parası, eşi çalışmayanlar için aile yardımı gibi kalemler adı altında maaşlarına ek ödenekler alırlar. Öğretmenlerin aldıkları ücretlerin, hayat standartlarıyla ilgili en önemli göstergelerden biri olduğu söylenebilir. Öğretmenlerin 
genel anlamda ne durumda olduklarını anlamak için maaşlarına bakılabilir (Erdem, 2010).

Cumhuriyetin ilanıyla birlikte daha fazla kurumsal kimlik kazanan öğretmenlik mesleğiyle ilgili günümüze kadar çeşitli sorunlar tartışılmış ve bu sorunlara çözüm önerileri getirilmeye çalışılmıştır. Bu çerçevede ortaya çıkan konular şu başlıklar altında sayılabilir:

- Öğretmen maaşlarının yetersizliğine bağlı olarak ekonomik sıkıntılar yaşanması.

- Diğer mesleklerle karşılaştırıldığında alınan düşük maaşın öğretmenliğin toplumdaki statüsüne etkisi.

- Öğretmen yetiştirme sisteminin istenilen ölçüde nitelikli öğretmen çıktısı verip vermediği tartışması.

- Öğretmenlerin mesleğe başladıktan sonra gelişimini devam ettirmede önemli bir unsur olan hizmet içi eğitim faaliyetlerinin yetersiz kalması (Sağlam ve Sağlam, 2005).

Öğretmenin diğer mesleklerde olduğu gibi toplumsal statüsünü ve saygınlığını belirleyen etkenlerden biri ekonomik durumdur (Aydın, 1999). Şahan (2003), öğretmenlerin ekonomik sorunlarını; maaşların düşük oluşu, köy okulları dışında lojmanlardan yararlanılamaması, birçok öğretmenin tek maaşla bir aileyi geçindirmek zorunda kalması, kendi eğitim ve gelişimine yeterli kaynak ayıramaması şeklinde siralamaktadir.

Öğretmenlerin işlerini hakkıyla yapabilmesi ve onlardan daha çok verim alınabilmesi için aldıkları ücretlerin tatminkar düzeyde olması gerektiği söylenebilir. Ev kirası, elektrik-su faturası gibi giderler düştükten sonra elinde kalan para ile bir ay nasıl hayıtını idame ettireceğini düşünen bir öğretmenin mesleğine istenilen düzeyde güdülenmesi kolay olmayacaktır. Ayrıca öğretmenlerin kişisel ve mesleki gelişimlerini sağlamak için hizmet içi eğitim, kurs, konser ve tiyatro gibi etkinliklere katılması gerektiği söylenebilir. Yine diğer çalışanlar gibi kitap, dergi ve gazete gibi yayınları takip etmeli, ailesiyle birlikte dışarıda vakit geçirebilecekleri yerlere gitmeli ve güzel bir tatil yapacak imkanlara sahip olmalıdır. Bu tür ihtiyaçları karşılanmayan öğretmenlerin kendileri mesleklerine vermeleri oldukça zor olacaktır. Hagemann (1997), çalışanların aldıkları ücretlerin kişinin aldığı evin kredi taksitini ödeyebilecek, dolabında şık kıyafetler olmasını sağlayacak, kara günlerde kendisini idare edebilecek, zaman zaman ailesiyle birlikte dışarıda vakit geçirebilecek ve hepsinden önemlisi bunlarda sonra tatil planlaması yapabilecek düzeyde olması gerektiğini ifade etmiştir. Bu düzeyde yüksek gelire sahip olan bir çalışanın maaşına yapılacak zam oranının kişinin iş gücü girdisini çok az etkileyecektir.

Maslow'un ihtiyaçlar hiyerarşisi kuramında da karşılanan bir gereksinimin güdüleyici olma özelliğini kaybettiği ve kişinin bir başka gereksinimi karşılamaya yöneldiği ifade edilmektedir. Ülkemizin sosyoekonomik koşullarında öğretmenler için maddi teşvikler daha fazla ön plâna çıkarılabilir. Çiçek (2002) tarafından, sınıf 
öğretmenlerini işe güdüleme yöntemleri konusunda yapılan araştırma sonuçlarına göre öğretmenler, mesleğin maddi yönden cazip hale getirilmesinin güdülemede çok önemli olduğunu ve maddî açıdan yapılacak iyileştirmelerden sonra diğer güdüleme yaklaşımlarının daha etkili olabileceğini belirtmişlerdir. Benzer şekilde Günbayı da (2001) öğretmenlerin iş doyumuna ilişkin olarak yaptığı araştırmasında, öğretmenlere yapılan ödemede iş doyumlarının düşük olduğunu belirtmektedir. Ayrıca, öğretmenlerin maaşlarının ve sosyal yardımlarının arttırılması durumunda iş doyumlarının yükselebileceğini ileri sürmektedir. Üstüner' de (1999) öğretmen morali konusunda yaptığı araştırma sonucunda, öğretmenlerin moral alt boyutlarından en az doyum sağladıkları boyutun maaş olduğunu saptamıştır.

Öğretmenlik mesleğinin saygınlığı ve saygınlığı etkileyen etmenlerden biri olan öğretmen maaşları hem öğretmenlerin hem de toplumun gündemini belirleyen konular arasındadır (Semerci ve Semerci, 2012). Bu çalışmada amaç, önemli bir ağ toplumu örneği olarak kabul edilen Twitter platformunda, kullanıcıların öğretmen maaşlarıyla ile Twitter ortamında kurdukları etkileşimi ve bu tür bir etkileşimi gerçekleştirirken dile getirdikleri düşünceleri analiz etmektir. Böylelikle kurulan etkileşimin hangi duygular ve kavramlar üzerinden gerçekleştiği anlaşılabilecektir. Bu çerçevede ağ üzerinde gerçekleşen etkileşimi \#̈̈̆gretmenmaasıyetmiyor adlı başlık etiketi örneklemi üzerinden anlamlandırabilmek için bir çalışma gerçekleştirilmiştir.

\section{Yöntem}

Bu bölümde araştırmanın yöntemi, araştırmanın modeli, çalışma grubu, geçerlikgüvenirlik çalışmaları, veri toplama süreci ve verilerin analiziyle ilgili bilgiler sunulmuştur.

\section{Araştırmanın Modeli}

Araştırmada nitel yöntem kullanılmıştır. Bu araştırma, öğretmenlerin karşılaştıkları ekonomik sorunlar ve maaş artışı talepleriyle ilgili görüşlerin belirlenmesi bakımından nitel araştırma desenlerinden olgu bilim çalışması (Fenomenolojik yaklaşım) niteliği taşımaktadır. Olgu bilim çalışmaları, bireylerin deneyimlerinden hareketle bir olay karşısındaki algılarını ve tepkilerini derinlemesine belirlemeye çalışır (Fraenkel, Wallen ve Hyun, 2011; Yıldırım ve Şimşek, 2011). Olgu bilimi yaklaşımı; hali hazırda konuyla ilgili bilgi üretilmiş bir olguyla çalışılırken kullanılabileceği gibi, yeni bir olguyu açıklamak amacıyla da kullanılabilir (Afyonoğlu, 2021). Tivitlerin (tweet) sözel veriler ve araştırmayla ilgili dijital medya içerikli çok fazla çalışmanın olmamasından hareketle konu yeni bir olgu olarak ele alınmıştır. Dolayısıyla araştırma nitel araştırma deseni ile tasarlanmış, ortaya çıkan fenomenleri betimlemek amacıyla olgu bilim yöntemi kullanılmıştır.

\section{Çalışma Grubu}

Einspänner, Dang-Anh ve Thimm (2014), sosyal medyada analiz yapmak için izlenmesi gereken adımları; örnekleme karar verme, veri toplama, veri analizi ve 
yorumlama olarak sıralamaktadır. Yazarlar örneklem seçiminde, kelime temelli kriter ve kullanıcı temelli kriter kullanılabileceğini belirtmektedir. Kelime temelli kriter; tivitlerin araştırma amacına göre başlık etiketleri (hastag) ya da anahtar kelimelerin aranması yoluyla örneklem belirlenmesi anlamına gelmektedir. Kullanıcı temelli kriter ise araştırma amacına göre seçilen belirli hesaplardan veri toplanması anlamına gelmektedir. Araştırmada çeşitliliğin sağlanabilmesi adına belirli hesaplar seçilmemiş, \#öğretmenmaasıyetmiyor adlı başlık etiketi ile arama yapılmış ve kelime temelli kriter kullanılarak veri toplanmıştır. Araştırmanın çalışma grubu, kelime temelli kriter seçimi doğrultusunda 6250 tivitten oluşmaktadır.

\section{Geçerlik-Güvenirlik Çalışmaları}

Araştırmanın geçerliği için:

- Öğretmenlerin karşılaştıkları ekonomik sorunlar ve maaş artışıyla ilgili alan yazındaki çalışmalar incelenmiş, kodlamalar yapilırken bu araştırma sonuçları dikkate alınmıştır.

- Verilerin toplanmasında, \#öğretmenmaasıyetmiyor başlığı üç gün boyunca konuyla ilgili atılan tivitler araştırmacı tarafından takip edilmiş ve süreçle ilgili notlar alınarak gerekli hassasiyet gösterilmeye çalışılmıştır.

- Görüşme içerikleri tüm ayrıntıları ile raporlanmıştır.

- Verilerin toplanması bizzat araştırmacı tarafından yürütülmüştür (Sevilmiş, 2020).

Araştırmanın güvenirliği kodlayıcılar arası güvenirlik ile değerlendirilmiştir. Ayn 500 tivit iki uzman tarafından kodlanmış ve iki kodlayıcının kodlama uyuşmaları çıkartılmıştır. Sonuçlar Uzlaşma / (Uzlaşma +Uzlaşmama).100 formülü ile hesaplanmıştır. $390 /(390+110) \cdot 100=\% 78$ olarak uzlaşma yüzdesi tespit edilmiştir. Kodlayıcılar arası uzlaşma nihai sonuçları değerlendirildiğinde kodlayıcılar arası uzlaşma yüzdelerinin yeterli seviyede olduğu tespit edilmiştir (Kuckartz and Rädiker, 2019).

\section{Veri Toplama Süreci ve Verilerin Analizi}

Çalışmada verileri değerlendirmek için betimsel analiz ve içerik analizi teknikleri birlikte kullanılmıştır. Betimsel analiz aşamasında öncelikle araştırmanın kavramsal çerçevesinden ve araştırma sorularından yola çıkılarak veri analizi için bir çerçeve oluşturulmuştur. Ayrıca katılımcıların anlatımlarına doğrudan yer verilmiştir (Yıldırım ve Şimşek, 2011). İçerik analizi ve tivit temalaştırması sosyal bilimlerde kullanılan yöntemlerden biridir (Sobaci ve Karkin, 2013, s.419). İçerik analizi, metinlerden veya diğer anlamlı verilerden, kullanım bağlamları doğrultusunda tekrarlanabilir ve geçerli çıkarımlar yapmak için belirli kodlara içeriklerin yerleştirilmesi şeklinde kullanılan bir araştırma tekniğidir (Krippendorff, 2004, s. 18). İçerik analizi genellikle çok sayıdaki metin içeriklerinin ortak yönlerini ortaya çıkarmak amacıyla, önemli olan anlamların yapılandırılmasını ve sınıflandırılmasını sağlayan bir yorum biçimidir (Gökçe, 2006, 17-18; Karadă̆, 2015, 
s.5). Çalışmada verilerin teker teker okunması yoluyla kod ve temalara dayalı olarak araştırma bulguları oluşturulmuştur (Merriam, 1998, s.58).

Veri analizine başlamadan önce \#öğretmenmaasıyetmiyor hastagi üç gün boyunca konuyla ilgili atılan tivitler araştırmacı tarafından takip edilerek veri toplama sürecine başlanmış ve notlar alınmıştır. İki gün sonra konuyla ilgili Twitter verileri MAXQDA programına aktarılmış ve tivitler tekrar okunmuştur. Bu doğrultuda veri temizleme süreci; \#öğretmenmaasıyetmiyor hastaginin aynı paragrafta geçtiği ancak \#öğretmenmaasıyetmiyor başlığıyla ilgili olmayan ya da konu dışı olan tivitler (beğeni almak için atılan vb.) analiz dışı bırakılarak gerçekleştirilmiştir.

Veri temizleme süreci sonrasında, çalışma gurubu üzerinden analiz edilen kullanıcıların ifadeleri olumlu ifadeler ve olumsuz ifadeler altında tasnif edilmiştir. Analiz için öğretmen maaşlarının yetersizliğiyle ilgili tivitlerin atıldığ \#öğretmenmaasıyetmiyor adlı başlık etiketi örneklem olarak belirlenmiş ve araştırmanın verisi bu başlık etiketi üzerinden toplanmıştır. 6250 tivitin çekildiği veri seti arasından yapılan ayıklama sonucunda toplam 5925 tivit belirlenmiş ve bu veri üzerinden 6139 kodlama yapılmıştır. Tivitler 23 Haziran 2021 ile 26 Haziran 2021 tarihleri arasında atılmıştır. Veri çekme esnasındaki temel sınırlılık, programın sadece son yedi gün içerisinde atılmış tivitleri çekilebilmesidir.

Tivitlerin kodlanmasında birbirleriyle ilişkili kodlar sınıflandırılarak olumlu ve olumsuz temalar oluşturulmuştur. Örnek olarak, "Maaş Artışını Destekleyen Kitle" kodlaması olumlu temasında yer alırken "Maaş Artışına Muhalif Kitle" olumsuz temada yer almıştır.

Bulgularda kullanılan alıntılar hem en çok retivit edilen tivitlerden hem de konuyla ilgili zengin bilgi birikimini yansıtabilecek tivitlerden seçilerek, doğrudan alıntılar kullanılarak sunulmuştur. En çok retivit edilen tivitlerin seçilme sebebi fenomenolojik yaklaşımın bir olguya dair perspektiflerden o olguya dair ortak özellikleri açığa çıkarma amacının yerine getirilmesiyken (Çarpar, 2020), doğrudan alıntıların kullanılma sebebi ise fenomenolojik yaklaşımda bir olguyu açılamak için kişilerin kendi deneyim ve düşüncelerini kendi anlattıklarıyla sunmak amacının sağlanmasıdır (Creswell, 2016). Sonuç olarak atılan 6250 tivit araştırmacı tarafından veri temizleme sürecine tabi tutulmuş ve kodlanılarak iki tema oluşturulmuştur. Kodlanan verilerin görsel analizinin yapıldığı incelemede kodların, Kod-Alt-Kod Bölümler Modeli, Kelime Bulutu ve Yüzde-Frekans analizleri yapılmıştır. Böylelikle dile getirilen düşünceler, duygular, inançlar vb. durumlar, temel kavram ve ifadeler ekseninde kodlanmış ve görselleştirilmiştir. 


\section{Bulgular}

Bu bölümde araştırmada elde edilen verilerin analizi sonucu elde edilen bulgular kapsamlı bir şekilde ele alınmıştır.

Öğretmen Maaşlarının Yetersizliğiyle İlgili Olumlu Temasına Ait Katılımcı Görüşleri

Maaş artışına olumlu bakan katılımcıların görüşleri bu tema altında kodlanmıştır. Öğretmen maaşlarının yetersizliğiyle ilgili olumlu temasına ait katılımcı görüşleri ilgili sonuçlar Şekil 1'de sunulmuştur.

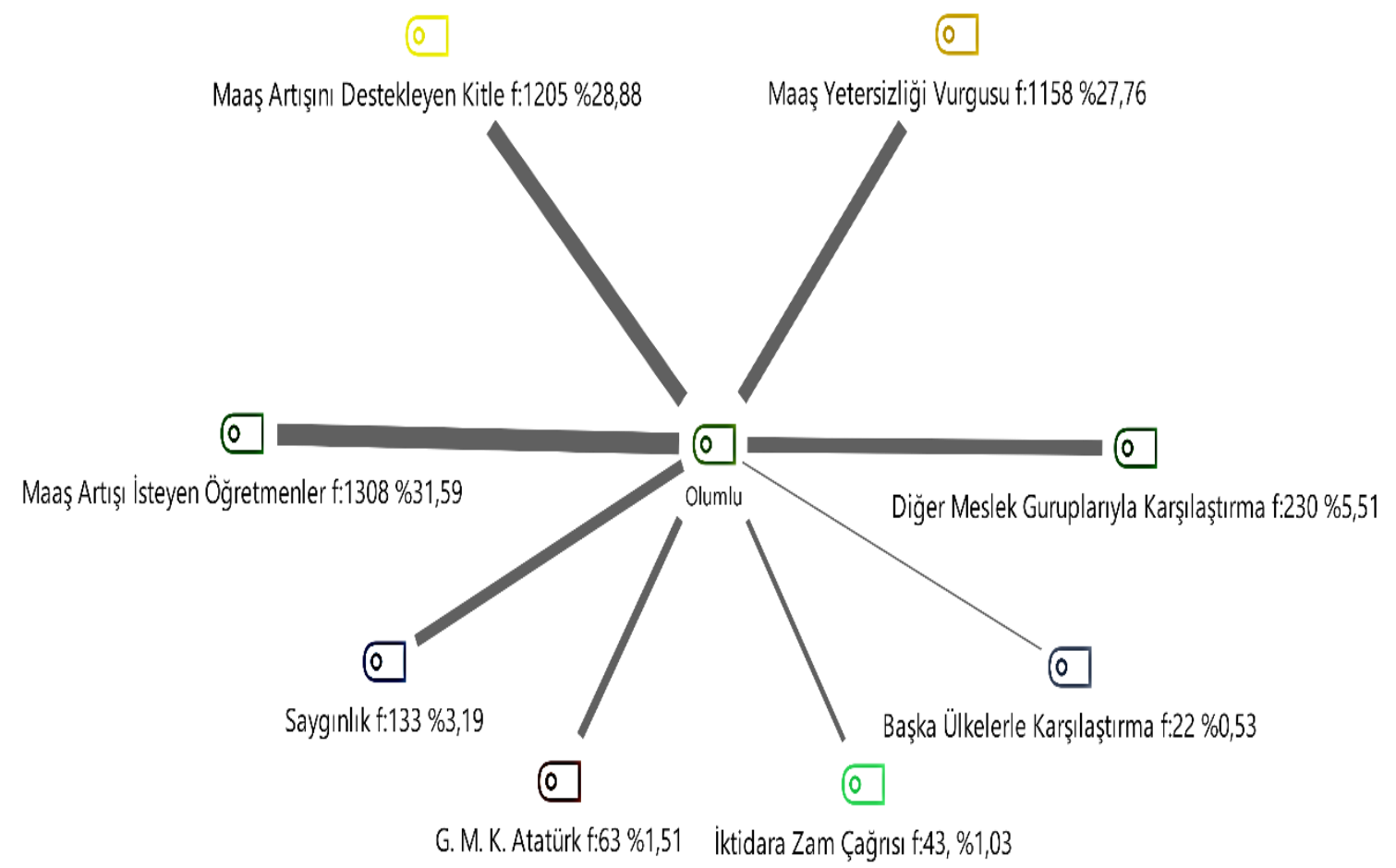

Şekil 1. Öğretmen maaşlarının yetersizliğiyle ilgili olumlu temasına ait kod-alt-kod bölümler modeli ve yüzde-frekans bilgileri

Şekil 1 incelendiğinde, hastag ile ilgili atılan tivitlerden öğretmenler tarafından yapılan paylaşımlar olduğu anlaşılan ve bu yüzden araştırmacı tarafından maaş artışı isteyen öğretmenler şeklinde kodlanan başlık \%31,59 oranıyla ilk sırada çıkmıştır. Katılımcıların konuyla ilgili görüşleri şunlardır.

Nesilleri yetiştirmeye çalışan biz öğretmenler, günlük faaliyetler dışında, 1) Kitaplar okumalıyız. 2) Sergiler, müzeler gezmeliyiz. 3) Farklı kültürleri tanıyacak aktiviteler yapmahyız. Bunun için de yeteri kadar parasal kaynağa sahip olmamız gerekiyor. \#äğretmenmaaşıyetmiyor

Asgari ücretli insanların olması neden hakkımızı aramamıza engel oluyor? Bir dilim ekmek bulamayan insanlar da var yemek yemeyelim o zaman? Tatil her çalışanın hakkl, ev araba her yaşam için gerekli şeyler. Öğretmenlere bunları çok mu görüyorsunuz? \#öğretmenmaaşıyetmiyor 
Maalesef herkesinki gibi öğretmen maaşı da gittikçe eridi, hiç oldu, anlamsız bir hal aldı. Ama hala şükredin halinize diyen var, şükretmek ayrı, hakkettiğin şekilde yaşamayı istemek ayrı. Hakkettiğinizi istemekten korkmayın. \#öğretmenmaaşıyetmiyor

Madem devlette öğretmen olmak çok kolay buyurun eğitim fakülteleri orda! Madem maaşı çok iyi madem çalışma şartları çok güzel Neden öğretmen olmuyorsunuz? Neden? \#öğretmenmaaşıyetmiyor

Öğretmen maaşlarının yetersizliğiyle ilgili maaş artışını destekleyen kitleye ait kod $\% 28,88$ oranla ikinci sırada çıkmıştır. Konuyla ilgili paylaşım yapanların ifadeleri şunlardır.

Geleceğimiz olan öğretmenlere haksızlık yapmayın, aldıkları maaş ne ev ne araba kredisi ödemeye yeter. Bir an önce iyileştirme yapılmalı \#öğretmenmaasıyetmiyor \#öğretmenmaaşıyetmiyor diyenler haklı. Ayrıca öğretmenlik çok zor bir meslek. Kolay değil. Biz evdeki birkaç çocukla zor uğraşıyoruz. Allah onlara yardım etsin.

Ben çocuğumun öğretmeninin maaşın düşünmesi yerine evladım için nasıl daha verimli olabileceğini düşünmesini isterim. \#öğretmenmaaşıyetmiyor'sa kafalarımı bu işe takmayacak kadar zam yapılmalıdır. \#geleceksenlegeleceköğretmenim. Bb \#iyikivarsın̈̈̆retmenim Öğretmenlerimiz: §૩̈̈̆grencisine ikaz etse veli mobingine

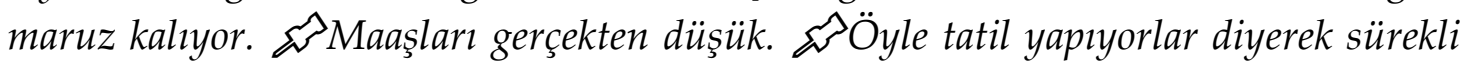
itibar suikastine uğruyorlar.

Maaş yetersizliği vurgusu koduyla ilgili katılımcıların kullandıkları ifadeler $\% 27,76$ oranıyla üçüncü sırada yer almaktadır. Katılımcı görüşlerine aşağıda yer verilmiştir.

Haberlerde yoksulluk sınırmın (4 kişilik bir ailenin)11.925€ olduğu haberi vardı. 32 yıllık bir öğretmenim ve eşim çalı̧̧ııyor, 3 kişilik bir aileyiz. Yani ben yoksul sinıfindayım. Yillarca oku, 30 kusur yıl devlete hizmet et ve aldığım maaş yoksulluk sinırında. \#̈̈ğretmenmaasıyetmiyor

ÖSS'de Türkiye'de ilk 2 bine girdim. İdeallerim vard öğretmen olacaktım. Bir gün bile pişman olmadım çocuklarımın yüzüne bakarken. Şimdi yaşadığım hayata bakıyorum içim buruk. Neden mesleğimi yaparken refah içinde yaşayamıyorum geçim kaygısı yaşıyorum? \#öğretmenmaaşıyetmiyor

4 ay önce sepetime ekleyip alamadığım kitaplar var! Ben bir eğitimciyim ve kitap alırken farklı önceliklerimi düşünmek zorundayım. Neden mi? Çünkü... \#öğretmenmaaşıyetmiyor

Kira:1525tl, Elektrik:180tl, Int:99tl, Su:50tl, Tel:60tl aylik ortalama 1750tl sabit giderim var. Mutfak masrafı, kredi kartı ve kredi borcumu eklemek istemiyorum bile gerisini siz düşünün...Bu arada doğuda para biriktirirsin diyenlere Başkale'den selam olsun! \#̈̈ğretmenmaaşıyetmiyor Bu ekonomik şartlarda öğretmenin kişisel gelişimi için bütçe ayırması hiç gerçekçi değil... 
Diğer meslek guruplarıyla karşılaştırma kodu \%5,51 oranla öğretmen maaşlarının yetersizliğiyle ilgili olumlu düşünceler temasında dördüncü sırada çıkmıştır. Ayrıca saygınlık kodu \%3,19 oranıyla beşinci sırada yer almıştır. Bu konulardaki katılımcı görüşlerine aşağıda doğrudan atıfta bulunulmuştur.

Meslek grupları içerisinde, kazancı en düşük gruplardan biri öğretmenlerdir. Hak eden her çalışana, hak ettiği maaş verilmelidir ve bunların başında öğretmenler gelmektedir. \#öğretmenmaasiyetmiyor

13 yıllık öğretmenim yeni başlayan lise mezunu bekçi kardeşim benden 1000 lira fazla alıyor (daha çok alsın hakkıdır), mezun edip işe başlayan öğrenci benden fazla maaş alabiliyor...Bu bize yapılan ayıptır günahtır...

Bekçi, polis, asker maaşında gözümüz yok lakin eğitim güvenlikten daha az önemli değildir. Bir şeyler yapılmalı. \#öğretmenmaaşıyetmiyor

Neymiş asgari ücretle geçinenler varmış. İyi de bu ülkede öğretmen kadar eğitimi olmayan ama 11 ayr yerden maaş alan bürokratlar var. Onlar niye örnek vermiyorsunuz laleler. \#öğretmenmaaşıyetmiyor

\#öğretmenmaaşıyetmiyor aldı̆̆ımız maaşa şükür ama hakkımız bu değil. Bizler geleceği inşa etmeye çalışıyoruz ama geçim derdinden önümüzü göremiyoruz. Bizler sadece hak ettiğimiz maaşı ve itibarı istiyoruz fazlasını de $\breve{g}$ il.

Öğretmene gerekli saygıyı bekliyoruz. Ekonomik olarak çok zorlanıyoruz. \#öğretmenmaaşıyetmiyor

\#öğretmenmaaşıyetmiyor mu bilmiyorum ama öğretmenliğin saygınliğının artması lazım sanırım bu da maddiyatla gerçekleşecek. Öğrencilerin rol model alacă̆ı insanlar şu an nerden nasıl para kazanırım derdindeler. Bunu yetinmemek olarak algılamayın lütfen.

4 yıllık fakülte mezunlar içinde en az maaş ile çalışanlar bizleriz herhangi bir yerde çalışan lise veya ortaokul mezunu bizlerden çok daha iyi ücret alıyor. Ücretle beraber saygınlı̆̆ımızda, itibarımız da kalmadı hepsi eridi gitti. Insanca yaşamak istiyoruz \#öğretmenmaaşıyetmiyor

Gazi Mustafa Kemal Atatürk'ün öğretmenlerle ilgili görüşlerine ait paylaşımlardan oluşan G.M.K. Atatürk kodu \%1,51 oranıyla altıncı sırada yer almıştır. Katılımcıların konuyla ilgili görüşleri şunlardır.

Sene 1923... Maliye Nazın Hasan Fehmi Ataç: "Paşam vekil maaşlarını düzenleyeceŏiz ne kadar verelim?" Mustafa Kemal Atatürk: "Öğretmen maaşlarını geçmesin." \#öğretmenmaaşıyetmiyor

Milletleri kurtaranlar yalnız ve ancak öğretmenlerdir. Öğretmenden, eğiticiden mahrum bir millet, henüz bir millet adını alma yeteneğini kazanamamıştır. MUSTAFA KEMAL ATATÜRK \#öğretmenmaaşıyetmiyor

Öğretmen maaşlarının yetersizliğiyle ilgili iktidara zam çağrısı yapan paylaşımların oluşturduğu kod \%1,03 oranla yedinci sırada yer almıştır. Son sırada ise 
$\% 0,53$ oranla öğretmen maaşları diğer ülkelerde yaşayan öğretmenlerin aldığı maaşlarıyla karşılaştırma yapılan paylaşımların oluşturduğu kod gelmiştir. $\mathrm{Bu}$ konulardaki katılımcı görüşlerine aşağıda sırasıyla doğrudan atıfta bulunulmuştur.

En az 1500 TL seyyanen zam istiyoruz. Pandemide herkese bol kepçe dağıtan devletimiz bizi de unutma \#öğretmenmaaşıyetmiyor

\#öğretmenmaaşıyetmiyor inşallah devletimiz öğretmenlerimizi ve memurlarımızı memnun edecek bir zam yapar yeni atama bekleyenlere müjdeli haberler verir

“Türkiye'de görev yapan öğretmenler, OECD ülkeleri arasinda ekonomik, sosyal ve özlük haklar açısından son sıralarda yer almayı sürdürüyor. \#öğretmenmaaşıyetmiyor https://t.co/NRPXHtEeD5

555 dolar maaş. TL değersiz. Avrupa'da öğretmenler 3 bin Euro alıyor. 5 maaş ile ayağını yerden kesecek polo araba alıyorlar 3 maaş ile Renault alıyorlar. Biz 45 maaş ile alabiliyoruz pes \#öğretmenmaaşıyetmiyor

\section{Öğretmen maaşlarının yetersizliğiyle ilgili olumsuz temasına ait katılımcı görüşleri}

Maaş artışına olumsuz bakan katılımcıların görüşleri bu tema altında kodlanmışır. Öğretmen maaşlarının yetersizliğiyle ilgili olumsuz temasına ait katılımcı görüşleri ilgili sonuçlar Şekil 2' de sunulmuştur.

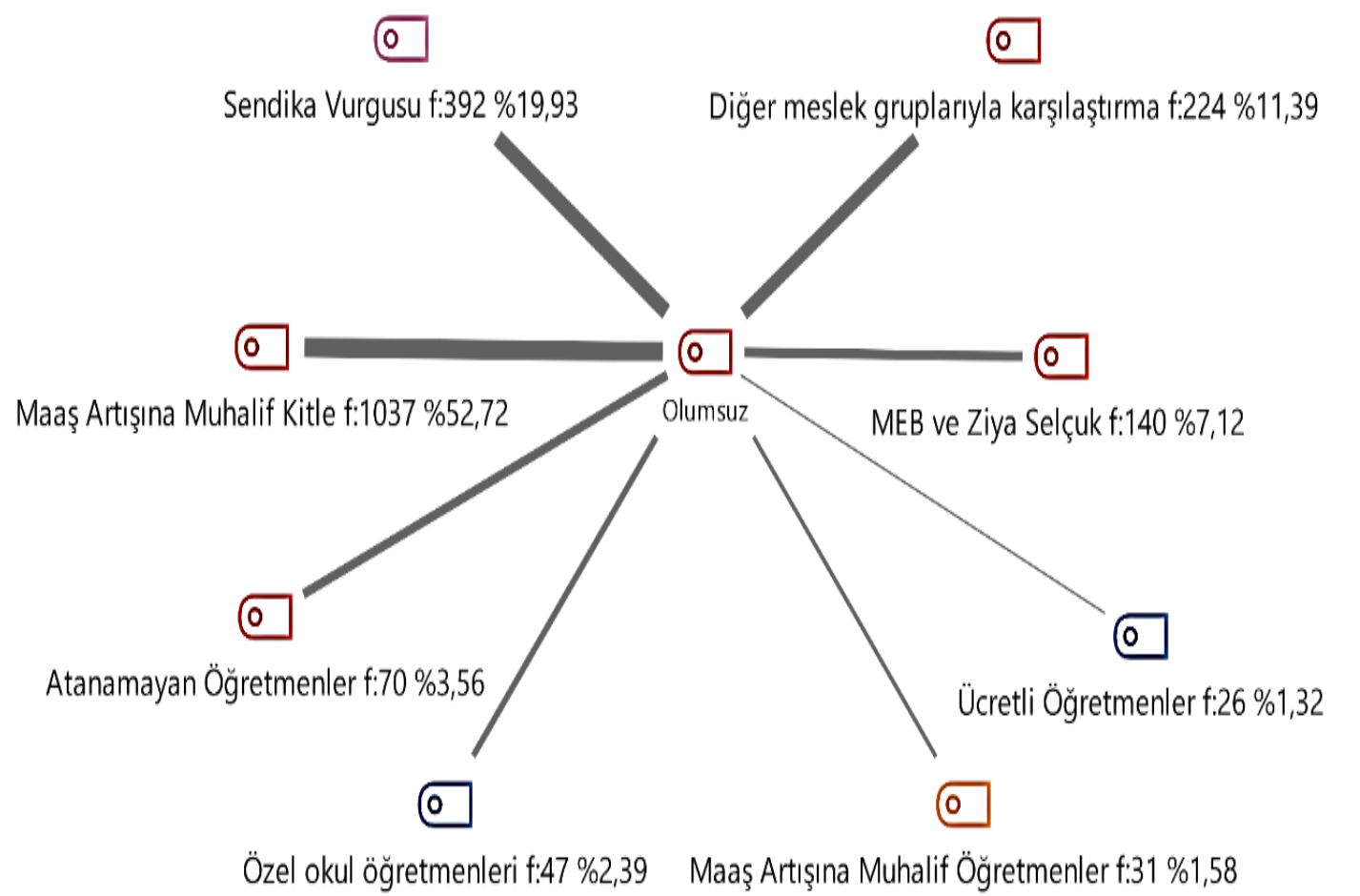

Şekil 2. Öğretmen maaşlarının yetersizliğiyle ilgili olumsuz temasına ait kod-alt-kod bölümler modeli ve yüzde-frekans bilgileri 
Şekil 2 incelendiğinde, öğretmen maaş artışına muhalif kitleye ait kod gurubu $\% 19,93^{\prime}$ lük oranla ilk sırada çıkmıştır. Konuyla ilgili paylaşım yapanların ifadeleri şunlardır.

Kamuda öğretmen maaşı fazlası ile yeterli. Yapılan işe göre yüksek rakamlar bunlar. Özelleşme şart verim alabilmek için. \#öğretmenmaaşıyetmiyor

Haftada 15 saat ders verip gerisini ek ders ücreti olarak alıyorsunuz. Part-Time çalışsanız 20 saat yapar. \#öğretmenmaaşıyetmiyor diye ağlamanın bir manası yok. Çünkü siz eğitim ödeneğini bile kendinize harcıyorsunuz. Evden eğitim için velilerden laptop isteyeniniz bile var.

\#öğretmenmaaşıyetmiyor Milyonlarca işsiz ve milyonlarca asgari ücretli var. Kusura bakmayın işinize gelmiyorsa istifa edin. Haklısını maaş az ama sizden aşağıları düşünün lütfen...

Allah gözünüzü doyursun yine çıkmıssınız sahneye gözü doymazlar. Aylardır okula gitmeden maaş al, gittiğiniz zamanda 180200 gün çalış gerisi tatil. Ek ders ile 70008000 maaş al ve hala utanmadan bu konuyu gündeme getir. Haram olsun aç gözlüler \#öğretmenmaaşıyetmiyor

Ben artık ülkenin eğitimci kitlesinin maaşlar hariç başka bir konuda fikir beyan etmeyip içindeki usulsüzlüklere sessiz kalmasına tahammül edemiyorum. Kusura bakmayın! \#OE ğretmenmaasiyetmiyor

Çocuğun okulundaki öğretmenlerin arabaların çekmiştim galeri gibi maşallah (1)옹 nasıl bir açlıktır arabayı satsa 10-15 yıl mutfak masrafı düşünmez \#oeğretmenmaastyetmiyor yersen https://t.co/OwR5Po2tel

Öğretmenler odasını "günlere çeviren " birbirlerine özel ders paslayan, müdürüyle sendikasıyla arasını iyi tutup keyfine göre program yaptıran, kendilerine etüt merkezi açıp öğrencilerini yönlendiren, dershanelerde çalışıp enerjisini orada harcayan \#öğretmenmaaşıyetmiyor

Ben pazarda limon çorap satan öğretmen görmüyorum geçinemediği için ek iş yapan öğretmen de görmüyorum ama ilanlarda lüks araç satan alan öğretmen çok görüyorum sanırım limon satmayı özlediler öğretmenler ALLAH doyursun.\#öğretmenmaaşıyetmiyor

Atılan tivitlerde sendika vurgusu yapan katılımcıların oranı \%19,93'tür. Konuyla ilgili paylaşım yapanların ifadeleri şunlardır.

\#öğretmenmaaşıyetmiyor sarı sendikayı başımıza musallat eden sözde öğretmenlerin maaşı yetmiyormuş, ulan sizin yüzünüzden her sene 3.5 zam almaktan usandım.

Her meslek grubunda bir birliktelik varken biz öğretmenler niye birlik olamıyoruz bunu da anlamıyorum. Benim tuzum kuru amannn bana ne diyemezsin. Sendikalarda üye toplamaya gelince yakanizı bırakmaz ama haklarımıza sıra gelince hemen pes ediyorlar. \#öğretmenmaaşıyetmiyor 
Kusura bakmayın ama korkudan ya da çıkar için yetkili sendikaya üye olup sonra maaşım yetmiyor demek ikiyüzlülük bence. Masada bakanla görüşüp devletin maaş zammını aşă̆ı çeken yetkili sendikadan istifa etsin sonra desin ki;\#̈̈ğretmenmaaşıyetmiyor

Ben sendikaların asli görevi olan memurların hakların koruma görevini yerine getirmediğini düşünüyorum. a sendika b sendika c sendika fark etmiyor hepsi ayn yolda buluşuyor \#öğretmenmaaşıyetmiyor

Yetkili sendika etkili değilse o zaman yetkiyi devretme zamanı gelmiştir. Öğretmen maaşlarn diğer kariyer meslekleri gibi yeniden düzenlemelidir. Ek zam zaruri ihtiyaçtır. \#öğretmenmaaşıyetmiyor

\#öğretmenmaaşıyetmiyor Sendikalar, öğretmenlerin haklarını savunmazsa öğretmenler sendikalardan ISTIFA etmeli diye düşünüyorum. Bunu yapabilecek kaç öğretmen vardır?

\#öğretmenmaaşıyetmiyor hak mücadele ile elde edilir. O da örgütlü toplumla olur. Çalışan için örgüt sendikadır. Hak aramayan sendika olmazsa o lafta sendikadır. Sendikacılık da birkaç yöneticiyle olmaz. Üyeler yönetimi zorlar. Sendika yönetimi iş yapmıyorsa başka sendikaya bakılır.

Herkes hak ettiği şekilde yaşar. Söz sahibi sendikadan belli değil mi eğitim camiasının kalitesi. Bu yüzden burada öğretmen maaşı yetmiyor diye sızlanmanın bir anlamı da yok. Önce sendikanızı değiştirin. Sarı sendikacılara söylüyorum. Ben de öğretmenim. \#öğretmenmaaşıyetmiyor

Öğretmen maaşlarının yetersizliğiyle ilgili olumsuz görüş bildirirken diğer meslek gruplarıyla karşılaştırarak örnek veren katılımcıların oranı \%11,39 ile üçüncü sırada gelmektedir. Katılımcı görüşlerine aşağıda yer verilmiştir.

\#öğretmenmaaşıyetmiyor. Yetmiyorsa başka mesleğe geçin. Sizin yerinize geçmek isteyen bir sürü insan var. Asgari ücretliler nasıl geçinsin? Onların hakkın savundunuz mu? Siz onların 2 katı maaş alıyorsunuz. Siz geçinemiyorsanız onlar nasıl geçiniyor diye hiç düşündünüz mü?

Ayıp ya bu ülkede 2.800 tl alıp kira verip ev geçindirenler var \#öğretmenmaaşıyetmiyor düşük model arabaya binersiniz lüks evlerde oturmazsinız olur biter

Ülkenin yarısı asgari ücretle çalışıyor siz 6.074 TL net maaş alıp o maaşı beğenmiyorsunuz. Özel okulda çalışan öğretmenlerden daha avantajlısınız. Özel okul öğretmenleri devlet daha fazla maaş veriyor diye devlete geçmek istiyor siz utanmadan ă̆lıyorsunuz \#öğretmenmaaşıyetmiyor

Sanki çok çalışıyorsunuz da bir de maaş yetmiyor diyorsunuz. Yazık be utanın! Siz tablet bilgisayar başındayken dükkanı iflas eden ya da inşaatlarda asgari ücretle çalışan adamlar ne yapsın. Yazıklar olsun. \#öğretmenmaaşıyetmiyor

Gerçekten çok nankörsünüz. Bu yüzden diğer meslekteki insanlar size bileniyor. Özelde sizin yarını maaşlara çalışıp 2 katınız derse giren öğretmenlerimiz bile bu kadar ă̆lamıyor. Asıl onların sesini yükseltmesi lazım! \#öğretmenmaaşıyetmiyor 
Pandemide ölümle burun buruna mücadele eden sağlık çalışanları dahi zam istemedi üstüne hayatların ortaya koydular kendilerinden ailelerinden vazgeçtiler siz ise pandemi boyunca 1,5 yıldır yatmaktan başka ne yaptınız hiçbir şey insanda biraz utanma olur ama o da sizde yok.\#̈̈ğretmenmaaşıyetmiyor

Aç gözlüsünüz 3200 lira maaşla on saat çalışıp haftada bir gün izinli olan işçiler var genç yaşta; onlardan utanın da açız kelimesini ona göre telaffuz edin ilk önce gözünüzü doyurup şükredin \#öğretmenmaaşıyetmiyor

MEB ve Ziya Selçuk kodu \%5,51 oranla öğretmen maaşlarının yetersizliğiyle ilgili olumsuz düşünceler arasında dördüncü sırada çıkmıştır. Ayrıca atanamayan öğretmen kodu \%3,56 oranıyla beşinci sırada yer almıştır. Bu konulardaki katılımcı görüşlerine aşağıda doğrudan atıfta bulunulmuştur.

Okul okul gezip sohbetler eden öğretmenlerle fotoğraflar çeken bakan acaba öğretmenlere geçinebiliyor musunuz diye soruyor mudur? \#öğretmenmaaşıyetmiyor Enflasyona karşı öğretmenini ezdirme MEB. \#öğretmenmaasıyetmiyor Özel okullar işleten, lüks evlerde oturup şatafatlı hayatlar yasayan, gelecek kaygısı olmayan insanları yönetici olarak başımıza getirirsek ne anlar 5 bin lira ile yasam mücadelesi veren insanların halinden? \#öğretmenmaaşıyetmiyor

Beni üzen asıl şey de Sayın bakanımız bu duruma bir kere bile değinmedi. Hatta maaşların yük olduğunu söyledi. O anda ne kadar sahipsiz olduğumuzu bir kez daha anladım. \#öğretmenmaaşıyetmiyor

2016'dan bu yana işsiz bir biçimde önce yüksek lisans yaptım. Şimdi doktora yapıyorum. Torpil olmadı̆̆ 1 için akademik kadroda yer alamadım. ALES=87 YDS=75 KPSS=80 puan ile 1000. oldum ama atanamadım. Yurt dışına kaçış planları yapıyorum! \#öğretmenmaasıetmiyor

\#öğretmenmaaşıyetmiyor diyen canım meslektaşlarım şu sıra o maaşı almak için aylarca KPSS çalışıyoruz hani bilin istedim .. beğgenmiyorsanız acaba sahneden aşă̆ $\mathrm{mi}$ alsak sizleri

Özel okul öğretmenlerinin çalışma koşulları ve aldıkları maaşlarla ilgili yapılan paylaşımlardan oluşan kod \%2,39 oranıyla altıncı sırada yer almıştır. Katılımcıların konuyla ilgili görüşleri şunlardır.

\#öğretmenmaaşıyetmiyor Özel Okullarda, kolejlerde üç kuruşa çalıştırılan öğretmenleri Milli Eğitim bakanımız neden görmezden geliyor. Tüccar okul sahipleri köle olarak çalıştırdıkları öğretmenlere köpek gibi davranıyor. İşten çıkartıyor, kovuyor, sigortasını yapturmuyor.

Sistem harika MEB öğretmeninin maaşı ortada hal böyle olunca da özel okullar asgari ücreti öğretmene verip köle gibi kullanıyor. Özel okuldaki öğretmenin günlü̈̆̈̈̈̈zel okul velisinin çocuğuna günlük verdiği harçlık kadar etmiyor. Buna inanın \#öğretmenmaaşıyetmiyor 
\#öğretmenmaaşıyetmiyor başlı̆̆ı açanlar özelde öğretmenlik yapmadı ve devletten 3 kat fazla çalışıp çok daha az maaşlarla geçinmeye çalışmadıysa demek...Şükür önemli tabi. Özel kurumlarda çalışan öğretmenlerin de sömürülmesi engellenmeli gerekli yasal düzenlemeler yapılmalı. Kurumlar bu anlamda denetlenmelidir. Asgari ücretle çalışan ögretmen mi olur. \#öğretmenmaaşıyetmiyor

Atılan tivitlerden öğretmenler tarafından yapılan paylaşımlar olduğu anlaşılan ve bu yüzden araştırmacı tarafından maaş artışına muhalif öğretmenler şeklinde kodlanan başlık \%1,58 oranıyla yedinci sırada çıkmıştır. Son sırada ise ücretli öğretmenlerin çalışma koşulları ve aldıkları maaşlarla ilgili yapılan paylaşımlardan oluşan kod \%2,39 oranında gelmiştir. Bu konulardaki katılımcı görüşlerine aşağıda sirasıyla doğrudan atıfta bulunulmuştur.

Ben de öğretmenim, 3 çocuğum var, eş yardımı dahil 6100tl maaş alıyorum, ek ders ile ortalama 6500 TL. Evim ve arabam var, çok şükür hiç kredi kullanmadım. Allah bereket versin maaşım yetiyor bir miktar da artıyor. Allah milletimize devletimize zeval vermesin \#öğretmenmaaşıyetmiyor

22 yıllık öğretmenim. Eşim de öğretmen. 1 yazlık 1 kışlık evim ve 1 yıllık sıfır otomobilim var. 5 yılda bir sifırlıyorum. Çocuğumun biri özel okulda ve diğeri de Anadolu lisesinde istediğimi yiyip geziyorum. Bizim okulda arabası olmayan hiç görmedim. \#öğretmenmaaşıyetmiyor

Ben de öğretmenim. Pandemi sürecinde o kadar insan işsiz kalırken, aylarca iş yerleri kapalı kalırken burada maaş konuşulması etik değil bence. \#OĔ̆gretmenmaasıyetmiyor

Benim okulun tablosu: -70 ögretmen, -hepsinin gayet modelli en az bir arabası var, -en az 50 kişinin en az bir evi var.-3/1 çocuğu özel okula gidiyor.- hobi, kamp, gezi, kıyafet, yeme içme yerleri muhabbetleri girla gidiyor. \#öğretmenmaaşıyetmiyor

Hamdolsun bize yetiyor \#öğretmenmaaşıyetmiyor. Bir öğretmen olarak düşüncem bu süreç de Rabbim esnafa çalışmayana asgari ücretliye yardım eylesin. Devlet ebed müddet. Allah devletimize zeval vermesin.

\#öğretmenmaaşıyetmiyor diyene nankör denir, ben de öğretmenim. Kusura bakmayın ama sayın meslektaşlarım 4500-5000'e de az diyorsanız yuh yani. Ben asgari ücret bile olsa mesleğimi yapma peşindeyim; ya ben çok idealist bakıyorum ya da enayiyim bilemiyorum \#öğretmenmaaşıyetmiyor

\#öğretmenmaaşıyetmiyor diyen öğretmenler, ücretli öğretmenlerin maaş yetersizliği için neden sessiz kalıyor? Oysa ki bu daha öncelikli bir sorun değil midir? Bu nasıl bir ögretmen ahlakıdır?

Her geçen sene gerçek enflasyon karşısında ezilen gelirler eğitim çalışanlarına hak değildir, ücretli öğretmenler için çözüm bulunmalıdır evet \#öğretmenmaaşıyetmiyor \#öğretmenmaaşıyetmiyor bir de ücretli öğretmenleri düşünün!!!! Posta memurunun bile ücretlisi yok 
4 ay boyunca ücretli öğretmenlik yaptım aldiğım en yüksek maaş 2300 liraydı. Devletin belirlediği asgari ücret 2800 devlet kendi bünyesinde çalışana 2300 maaş veriyor \#öğretmenmaaşıyetmiyor

\#öğretmenmaaşıyetmiyor. Öğretmenler okuyor atanamıyor branşı olmayan maaşının üçte biri olan derslere ücretli öğretmen olarak giriyor \#öğretmenmaaşıyetmiyorÜcretli öğretmen, sözleşmeli öğretmen vs diye bizi sinıflandırdılar. Mesleğimiz ayaklar altında sırf bu yüzden. Eşit iş ve eşit maaş istiyoruz \#öğretmenmaaşıyetmiyo

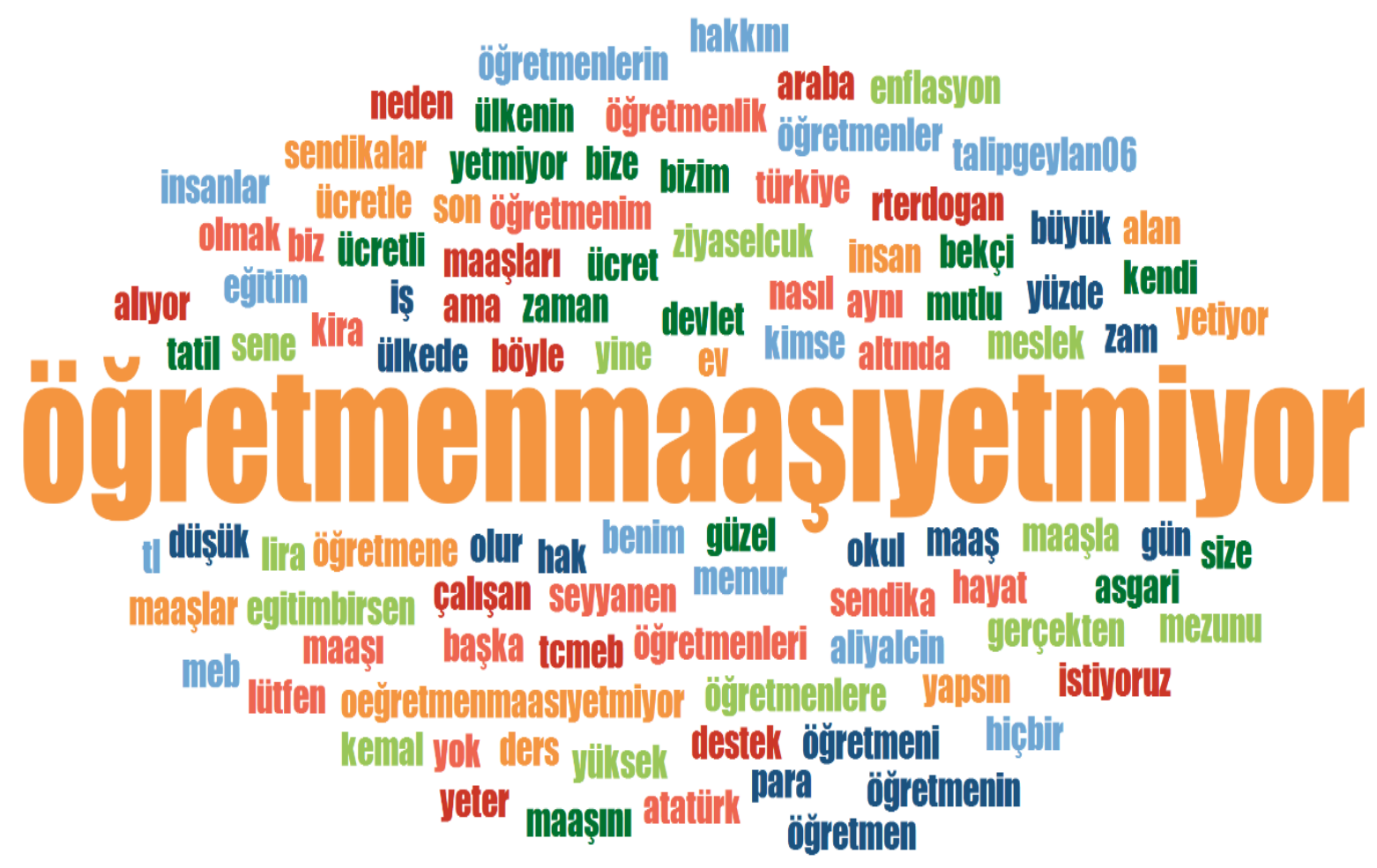

Şekil 3. Kodlu bölümlerde geçen kelimelerin sıklı̆̆ını gösteren kelime bulutu

Kodlu bölümlerde kullanıcıların en çok hangi ifadeleri kullandığı da analiz edilmiştir. Bu analiz türünün önemi bir olay, gündem ya da konuyu takip eden kullanıcıların amacını, eğilimini, istem ve arzularını, inanç ve tahminlerini anlamlandırmaya yarayacak sonuçlar vermesidir. Kelime bulutu şekillenirken kullanıcıların en çok yinelediği sözcük bulutun merkezinde konumlanmıştır. Puntolarının büyüklügüne göre en sık yinelenen kelimeler en büyük olacak şekilde büyükten küçüğe doğru sıralanmaktadır (Bulut, 2020). Şekil 3 incelendiğinde, kelime bulutunda yer alan öğretmen maaşı yetmiyor, ücret, sendika, MEB, Ziya Selçuk, yeter, ücretli öğretmen ve şükür gibi kelimeler öğretmen maaşlarının yetersizliğiyle ilgili yüzde-frekans bilgileri bulgularıyla örtüşmektedir. 

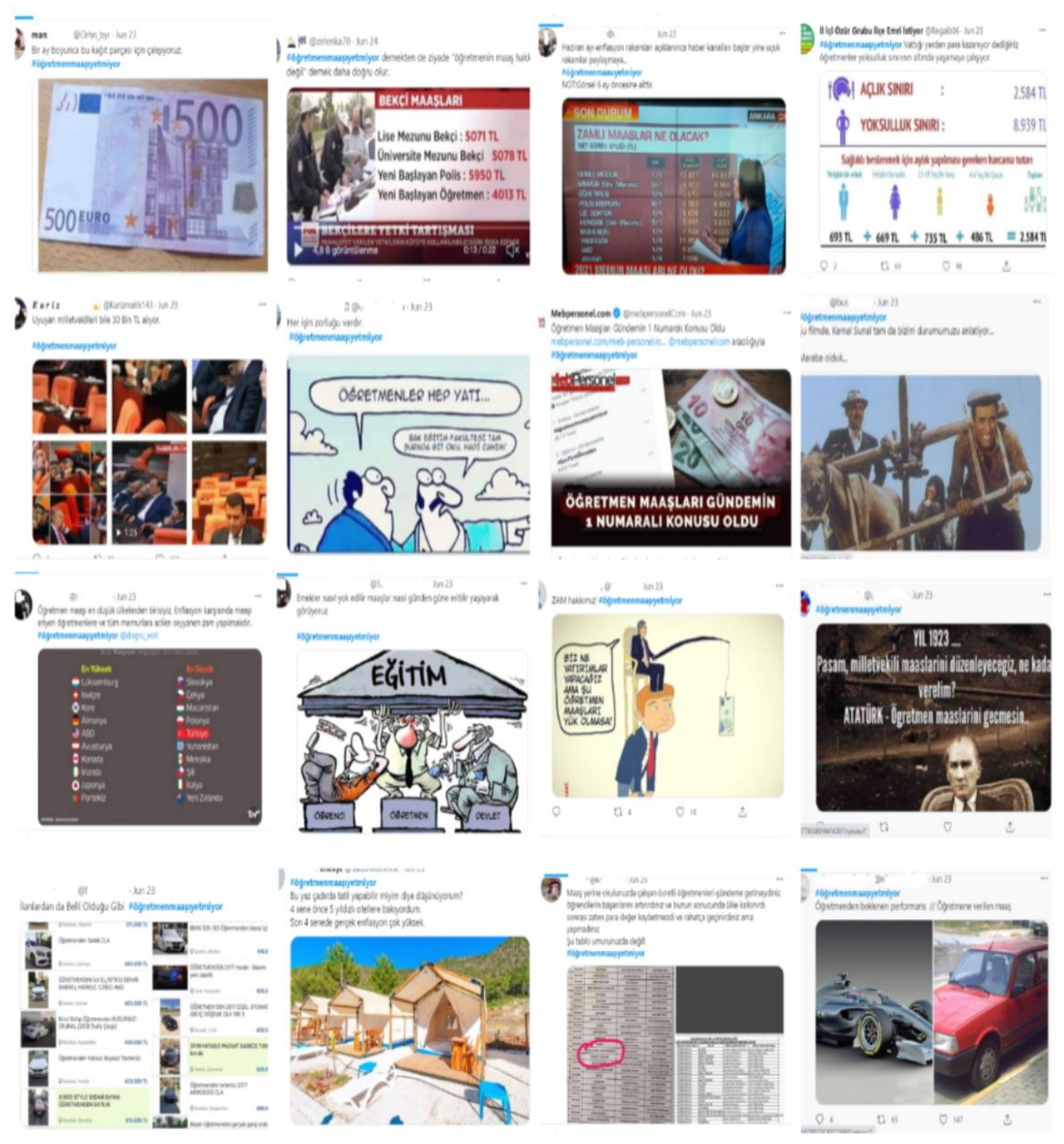

Şekil 4. Paylaşımlarda kullanılan fotoğraflardan örnekler

Şekil 4'te \#̈̈ğretmenmaasıyetmiyor hastagine yönelik yapılan paylaşımlarda kullanılan fotoğraflara yönelik bazı örnekler sunulmuştur. Paylaşılan fotoğraflar incelendiğinde, resimlerde yer alan öğretmen maaşının zaman içinde değer kaybettiği, diğer meslek guruplarıyla yapılan karşılaştırmalar, saygınlık, diğer ülkelerdeki öğretmen maaşları, öğretmen maaşlarının yetersizliği vurgusu ve Atatürk'ün öğretmenlerle ilgili görüşlerine ait paylaşımlar öğretmen maaşlarının yetersizliğiyle ilgili olumlu temasına ait kod-alt-kod bölümler modeliyle örtüşmektedir. Ayrıca yine öğretmen maaş artışına muhalif kitle koduyla yer alan görüşlere ait resimlerde benzer şekilde katılımcılar tarafından paylaşılmıştır. 


\section{Sonuç ve Tartışma}

Araştırma sonunda olumlu temada maaş artışı isteyen öğretmenler, maaş artışını destekleyen kitle, maaş yetersizliği vurgusu, diğer meslek guruplarıyla karşılaştırma, saygınlık, G.M.K. Atatürk kodu ve iktidara zam çağrısı kodlarının yer aldığı görülmektedir. Olumsuz temada ise maaş artışına muhalif kitle, sendika vurgusu, diğer meslek gruplarıyla karşılaştırma, MEB ve Ziya Selçuk kodu, özel okul öğretmenleri, maaş artışına muhalif öğretmenler ve ücretli öğretmenler kodları çıkmıştır. Bu sonuçlar genel olarak yorumlandığında; öğretmenlerin yaptıkları görevi gerek küresel salgın döneminde gerekse normal dönemde önemli ve değerli bulan bir çoğunluk varken, azımsanamayacak bir oranda da öğretmenlerin yaptıkları işle orantılı oranla fazla maaş aldıklarını ve ülke ortalamasının üstünde imkanlara sahip olduklarını düşünen bir kitlenin bulunduğu sonucuna ulaşılmıştır. Hatta bu gurup içinde öğretmenlere ağır hakarette bulunan ve yaptıkları işi değersiz gördüklerini çok çirkin ifadeler kullanarak belirten bir gurubun olduğu söylenebilir. Attıkları tivitlerden öğretmen olduğu anlaşılan katılımcıların büyük bir kısmının maaş artışı istediği ve maaş yetersizliğini vurguladığı tespit edilirken çok az bir gurubun maaşın yeterli olduğunu düşündükleri sonucuna varılmıştır. Araştırmanın bu bulgusu iki sendikanın yaptığı çalışmalardaki öğretmenlerin aldıkları maaşları yetersiz bulduğu sonucuyla benzerlik göstermektedir (Türk Eğitim Sen, 2020; Eğitim Sen, 2020). Ayrıca öğretmenler maaş yetersizliğiyle birlikte mesleki saygınlıklarının da azaldığını ve toplum içinde değer kaybettikleri noktasında görüş belirtmiştir. Bu sonuç Türk Eğitim Sen'in (2020) çalışmasıyla benzerlik göstermektedir. Sendikanın anketine katılan eğitimcilerin \% 69,8'i öğretmenliğin toplum tarafından saygın bir meslek olarak görülmediğini ifade etmiştir. Olumsuz tema içinde sendika vurgusu önemli oranda dile getirilen bir başka konu olmuştur. Bu bulgu, Aksoy'un (2013) lise öğretmenleri üzerinde yaptığı araştırmasında sendikal örgütlenmeye ilişkin görüşlerin daha çok hakların savunulması üzerinde yoğunlaştığı sonucuyla örtüşmektedir. Öğretmenlerin aldıkları ücretler diğer meslek guruplarıyla hem olumlu tema hem de olumsuz tema karşılaştırılarak katılımcılar tarafından dile getirilmiştir.

Öğretmenler ücretlerini diğer meslek guruplarıyla karşılaştırırken bekçi maaşlarının ve düşük eğitim almış meslek guruplarının kendilerinden fazla kazandıklarını vurgulamıştır. Bu sonuç, öğretmenlerin hukuki anlamda herhangi bir devlet memuru statüsünde bulunması ve öğretmenlik meslek kanunun henüz yasalaşmamış olması özlük hakları noktasında önemli bir sorun olduğu şeklinde yorumlanabilir. Öğretmenlerin gelirleri kendi seviyelerinde eğitim alan ve lisans eğitimi altında öğrenim gören mesleklerle karşılaştırıldığında en alt seviyelerde olduğu söylenebilir (Bek, 2007; Torun, 2010). Öğretmen maaşının yaptıkları işe oranla yüksek olduğunu düşünen ve olumsuz temada yer alan gurup asgari ücretle çalışan kesimin yaptıkları işten ve aldıkları maaş üzerinde durmuştur. Ayrıca özel okul öğretmelerinin, MEB'de çalışan ücretli öğretmenlerin, sağlık çalışanlarının, güvenlik güçlerinin ve işçilerin çalışma koşullarına göre kazandıkları ücretleri düşünerek öğretmenlerin maaş artışı istememesi gerektiğini ifade etmişlerdir. Ücretli 
öğretmenlerle ilgili ulaşılan sonuç, Eğitim Sen'in (2020) araştırmasındaki “Sözleşmeli ve ücretli öğretmenlerin kadrolu öğretmenlerle eşit haklara sahip olduğunu düşünüyor musunuz?" sorusuna yüzde 90'ın üzerinde "Hayır" yanıtı verilmiş olması bulgusuyla paralellik göstermektedir.

Yetenekli ve başarılı gençleri öğretmen olarak çalıştırabilmek için, öğretmenliğin yüksek statüde bir meslek haline getirilmesi için maaş ve çalışma koşullarının iyileştirilmesi gerektiği söylenebilir. Ayrıca öğretmenlerin sosyal statülerine katkı yapacak çalışmaların da yapılması yararlı olacaktır. Bununla birlikte, öğretmenlerin toplum gözünde kültürel olarak değeri artırılamazsa, tek başna iyi ücretlerin yeterli olmayacağı gerçeği de unutulmamalıdır. Öğretmenlere ödenen ücretin ve sağlanan olanakların yeterli düzeye ulaşmamasının yanında öğretmenler pek çok olanaktan yoksun bir şekilde memleketin en ücra köşelerinde hizmet vermektedir. Bu bölgelerde çalışan öğretmenlere ek ödeneklerin verilmesinin onların çalışma güdülerini artırıcı yönde etki yapacağı söylenebilir.

Eğitim sisteminin dışında iş bulamama ve sayıca çok olma, öğretmenleri hak ettiklerinden daha az maaşla özelde ve MEB'de çalışmaya razı etmektedir. Denklik kuramına göre bir iş gören, aldığı ödemeye denk emek harcar. Öğretmenlere emeklerinin karşıllğııı vermemek, eğitimin maliyeti ile niteliğini de düşürmektedir. Eğitimin niteliğinin düşmesi de ülkenin gelişmesi açısından olumsuz sonuçlar doğurmaktadır. Bu çerçevede MEB'de ücretli öğretmenlik kavramının kaldırılmasının doğru bir yaklaşım olacağı söylenebilir. Ayrıca özel okullarda çalışan öğretmenlerin düşük veya asgari ücretle çalıştığ 1 düşünüldüğünde bu öğretmenlik mesleği için ciddi bir sorun alanıdır. Özel okulda çalışan öğretmenler için de devletin gerekli yasal düzenlemeler yaparak düşük ücretle öğretmen çalıştırılmasının önüne geçmesi gerekmektedir.

Öğretmenler var olan ekonomik sıkıntılar nedeniyle kendilerini mesleğine verememektedirler. Genç kuşakların iyi yetiştirilmesi, ülkenin çok yönlü gelişmesi açısından çok önemli görüldüğünden, öğretmenlerin işlerini en iyi şekilde yapabilmeleri için başta ekonomik sorunlar olmak üzere mesleğe ilişkin çeşitli sorunlar acilen çözüme kavuşturulmalı ve öğretmenlik mesleğinin cazip hâle getirilebilmesi için ekonomik bakımdan öğretmenin durumunun, toplumda gelir düzeyi yüksek olan diğer meslek çalışanlarının durumuna getirilmesi gerekmektedir.

Öğretmenlerin yaptıkları paylaşımlarda öne çıan sendika vurgusundan hareketle kamu çalışanlarının sendikal hakları uluslararası belgelerde şekillenen normlar dâhilinde iyileştirilmesi gerektiği söylenebilir. Ayrıca siyasi iradeyle yapılan ücret pazarlıklarında memurların masada güçlü olabilmesi için sendikaların çalışmalarını artırarak grev hakkı elde etmesi gerekmektedir.

Çalışma nitel araştırma yöntemiyle yapıldığından analitik genellemeler dışında sonuç ve öneriler getirilebilmesi için nicel bir ölçme aracı geliştirilerek yapılacak bir araştırmanın yararlı olacağı söylenebilir. 


\section{Etik Beyan}

“Öğretmenlerin Karşılaştıkları Ekonomik Sorunlar ve Maaş Artışı Talepleriyle İlgili Görüşleri: Twitter Analizi" başlıklı çalışmanın yazım sürecinde bilimsel, etik ve alıntı kurallarına uyulmuş; toplanan veriler üzerinde herhangi bir tahrifat yapılmamış ve bu çalışma herhangi başka bir akademik yayın ortamına değerlendirme için gönderilmemiştir.

\section{Kaynaklar}

Afyonoğlu, M. F. (2021). Sosyal hizmetin sorunlarına twitter üzerinden bakmak: Eğitim ve istihdam sorunu. Toplum ve Sosyal Hizmet, 32 (3); 1021-1044. https://doi.org/10.33417/tsh.915534

Aksoy, M. (2013). Lise öğretmenlerinin sendikal örgütlenmeye bakışları: Eskişehir ili örneği. (Yayımlanmamış Yüksek Lisans Tezi). Anadolu Üniversitesi Sosyal Bilimler Enstitüsü, Eskişehir.

Aydın, İ. (1999). Dünden bugüne öğretmenler (1965-2005). Eğitim Sen Yayınları.

Bek, Y. (2007). Öğretmenin Toplumsal/ Mesleki Rolleri ve Statüsü. (Yayımlanmamış Yüksek Lisans Dönem Projesi) Trakya Üniversitesi Sosyal Bilimler Enstitüsü, Edirne.

Bulut, S. (2020). A $\breve{g}$ toplumunda parasosyal etkileşimi twitter kullanıcı yorumları üzerinden değerlendirmek. INIFF E-Dergi, $5 \quad$ (2), 43-59. https://doi.org/10.47107/inifedergi.808837

Creswell, J. W. (2016). Nitel araştırma yöntemleri. Siyasal Kitabevi.

Çarpar, M. C. (2020). Sosyolojide iki temel niteliksel desen: Fenomenolojik ve etnografik araştırma. The Journal of Social Science, 4 (8), 689-704. https://doi.org/10.30520/tjsosci.750923

Çiçek, A. (2002). İlköğretim okulu yöneticilerinin sını öğretmenlerini güdülemede kullandıkları yöntemlere ilişkin yönetici ve öğretmen görüşleri. (Yayımlanmamış Doktora Tezi). Ankara Üniversitesi, Ankara.

Egitim-Sen (2020). Öğretmenlerin ekonomik ve mesleki sorunlarına bakış anketi. https://egitimsen.org.tr/ogretmenlerin-ekonomik-ve-mesleki-sorunlarina-bakisanketi-sonuclari/

Erdem, A. R. (2010). İlköğretim ve ortaöğretim öğretmenlerinin karşılaştığı ekonomik sorunlar ve bu ekonomik sorunların performanslarına etkisi konusundaki görüşleri, Uluslararası İnsan Bilimleri Dergisi, 7 (1), 270-287.

Einspänner, J., Dang-Anh, M., \& Thimm, C. (2014). Computer-Assisted content analysis of twitter data. In Weller, K., Bruns, A., Burgess, J., Mahrt, M. \& Puschmann, C. (Ed.), Twitter and society, (pp.97-108). Peterlung Publishing.

Fraenkel, J.R. Wallen, N.E., \& Hyun, H.H. (2011). How to design and evaluate research in education (Eight edition). McGraw-Hill.

Gökçe, O. (2006). İçerik analizi: Kuramsal ve pratik bilgiler. Siyasal Kitabevi. 
Göker, S. D., \& Gündüz, Y. (2017). Dünya ölçeğinde öğretmenlerin saygınlık statüsü ve özlük hakları, Milli Eğitim Dergisi, $46 \quad$ (213), https://dergipark.org.tr/tr/pub/milliegitim/issue/36137/405976

Günbayı, İ. (2001). İlköğretim okulu öğretmenlerinin iş doyumu, Kuram ve Uygulamada Eğitim Bilimleri, 1 (2), 93-112.

Hacıoğlu, F. \& Alkan, C. (1997). Öğretmenlik uygulamaları. Alkım Yayınları.

Hagemann, G. (1997). Güdüleme el kitabı (Çev: Göktuğ Aksan). Rota Yayınları.

Helvacı, A. M. (2007). Öğretmenlik mesleğinin özellikleri. Nevin Saylan (Ed.), Eğitim Bilimine Giriş, içinde (s. 315-321). Anı Yayıncılık.

Karadağ, R. (2015). Okuma ilgisi, tutumları ve alışkanlığı konusunda yapılmış çalışmaların lisansüstü tezlere dayalı analizi: YÖK ve ProQuest veri tabanları örneklemi, Pamukkale Üniversitesi Ĕ̆itim Fakültesi Dergisi, 35 (1), 1-17.

Krippendorff, K. (2004). Content analysis: An introduction to its methodology. Sage Publications.

Kuckartz, U., \& Rädiker, S. (2019). Analysing qualitative data with MAXQDA. Springer International Publishing.

Merriam, S. B. (1998). Qualitative research and case study applications in education. revised and expanded from case study research in education. Jossey-Bass Publishers,

Şahan, G. (2003). Öğretmen sorunları ve çözüm önerileri. Eğitim ve Denetim, 1(11), 21-25.

Sağlam, M., \& Sağlam, A. Ç. (2005). Öğretmenlik mesleğinin maddi yönüne ilişkin genel bir değerlendirme. Türk Ĕ̆itim Bilimleri Dergisi, 3(3), 317-328.

Semerci, Ç., \& Semerci, N. (2012). Öğretmenlik mesleğinin gündemine ilişkin öğretmen görüşleri (Bartın ili örneği), Bartın University Journal of Faculty of Education, 1(1), 2240 .

Sevilmiş A. (2020). Türk futbolunda bir deprem Ünal Karaman krizinin spor siyaset ilişkisi bakımından değerlendirilmesi: Twitter analizi. 18. Uluslararası Spor bilimleri Kongresi, 798-806, Konya.

Sobac1, M. Z., \& Karkın, N. (2013). The use of Twitter by mayors in Turkey: Tweets for better public services? Government Information Quarterly, 30, 417-425. https://doi.org/10.1016/j.giq.2013.05.014

Tok, T. N. (1997). Öğretmenlik mesleğinin öğretmenlerin gereksinimlerini karş1lama düzeyi. Kuram ve Uygulamada Eğitim Yönetimi, 10(10), 251-267.

Türk Devrim Tarihi Enstitüsü, (1961). Atatürk'ün söylev ve demeçleri, cilt. l. Ankara,

Türk Eğitim Sen, (2020). 24 Kasım öğretmenler günü anketi. https://turkegitimsen.org.tr/icerik goster.php?Id=13814.

Üstüner, M. (1999). Okul yöneticilerinin öğretmenleri etkilemede kullandıkları güçler ve öğretmen morali, (Yayımlanmamış Doktora Tezi), H.Ü. Sosyal Bilimler Enstitüsü, Ankara.

Varkey Gems Foundation (2013). Teacher status index. London. 
Yıldırım, A. \& Şimşek, H. (2011). Sosyal bilimlerde nitel araştırma yöntemleri. Seçkin Yayınevi. 